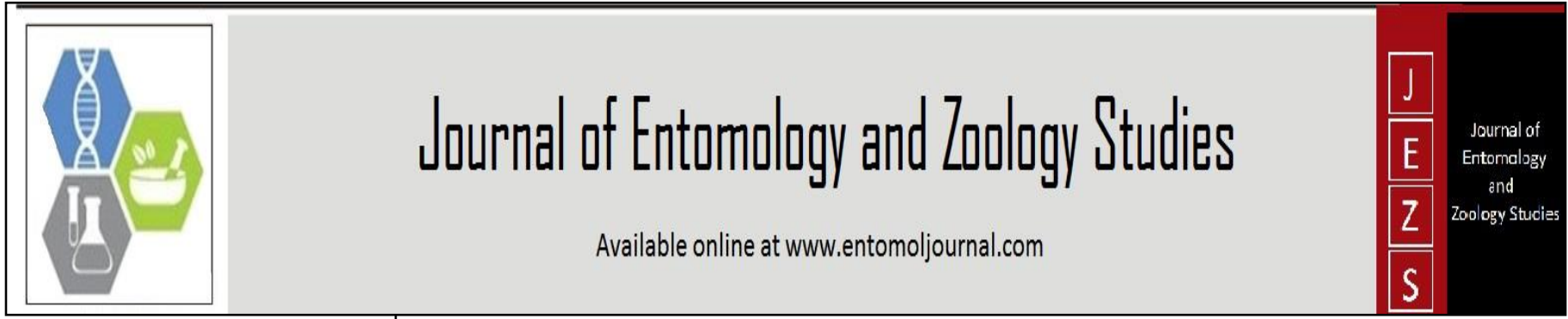

E-ISSN: 2320-7078

P-ISSN: 2349-6800

www.entomoljournal.com JEZS 2021; 9(1): 564-571 (C) $2021 \mathrm{JEZS}$

Received: 27-10-2020

Accepted: 25-12-2020

Shreya Dubey

M.V.Sc. Scholar, NDVSU, Jabalpur, Madhya Pradesh, India

\section{Ranvijay Singh}

Associate Professor, NDVSU, Jabalpur, Madhya Pradesh,

India

\section{Bhavana Gupta}

Assistant Professor, NDVSU, Jabalpur, Madhya Pradesh, India

\section{Renuka Pate}

M.V.Sc. Scholar, NDVSU, Jabalpur, Madhya Pradesh, India

Divya Soni

M.V.Sc. Scholar, NDVSU, Jabalpur, Madhya Pradesh, India

\section{BMS Dhakad}

M.V.Sc. Scholar, NDVSU, Jabalpur, Madhya Pradesh, India

Boreddy Manoj Reddy M.V.Sc. Scholar, NDVSU, Jabalpur, Madhya Pradesh, India

\section{Shivani Gupta}

M.V.Sc. Scholar, NDVSU, Jabalpur, Madhya Pradesh, India

\section{Nidhi Sharma}

M.V.Sc. Scholar, NDVSU, Jabalpur, Madhya Pradesh, India
Corresponding Author: Shreya Dubey M.V.Sc. Scholar, NDVSU, Jabalpur, Madhya Pradesh, India

\section{Leptospira: An emerging zoonotic pathogen of climate change, global warming and unplanned urbanization: A review}

\author{
Shreya Dubey, Ranvijay Singh, Bhavana Gupta, Renuka Patel, Divya \\ Soni, BMS Dhakad, Boreddy Manoj Reddy, Shivani Gupta and Nidhi \\ Sharma
}

DOI: https://doi.org/10.22271/j.ento.2021.v9.i1h.8207

\begin{abstract}
Leptospirosis is a worldwide zoonotic infection with a much greater incidence in tropical regions and has now been identified as one of the emerging infectious diseases. The epidemiology of leptospirosis has been modified by changes in animal husbandry, climate and human behavior. Resurgent interest in leptospirosis has resulted from large outbreaks that have received significant publicity. The transmission cycle of leptospirosis involves maintenance hosts, carrier hosts, environment and human beings. The carrier animals in India include rats, pigs, cattle, bandicoots and dogs. Intervention strategies include vaccination, rodent control and improved environmental hygiene to eliminate possibility of water, soil and food contamination. Mass awareness or public education is of utmost importance. The development of simpler, rapid assays for diagnosis has been based largely on the recognition that early initiation of antibiotic therapy is important in acute disease but also on the need for assays which can be used more widely. The gold standard is microscopic agglutination test though serological studies are widely conducted for the diagnostic purpose. The antibiotics use for the treatment of leptospirosis includes oral doxycycline, azithromycin and penicillins. Among the parenteral therapy Intravenous penicillin $G$ and third generation cephalosporins are used. We reviewed the clinical presentation, diagnosis, treatment and prevention of leptospirosis in this study.
\end{abstract}

Keywords: Leptospirosis, serovar, climate change, emerging zoonosis, environmental hygiene

\section{Introduction}

Leptospirosis is a zoonotic, waterborne, neglected, reemerging bacterial disease of public health importance. Due to rapid, unplanned urbanization and poor sanitation, leptospirosis emerges as a leading cause of acute febrile illness in many of the developing countries. With rapid global urbanization about 68 percent of the world's human population projected to be living in urban areas by the year $2050{ }^{[53]}$ (55 percent as of 2018). Wild rats seem to benefit from urbanization and thrive in urban and domestic environments, leading to frequent human exposure to these species ${ }^{[4]}$. Leptospirosis is rat-associated zoonotic disease. $R$. norvegicus and $R$. rattus have become ubiquitous in urban environments and are significant sources of many zoonotic pathogens that can result in mortality and morbidity in humans and animals. Because of knowledge gaps in the ecology of rats, rat control is largely ineffective. India with an $8,129 \mathrm{~km}$ long coastline and with endowment of plenty of natural resources has one of the major important coastal, agro-ecosystem that supports livelihood of several million people thus outbreaks of leptospirosis had been reported from tropical and coastal districts of Gujarat, Maharashtra, Kerala, Tamil Nadu, Andhra Pradesh, Karnataka, Andamans, Goa and Orissa. It is estimated that annual rates of infection vary from 0.02 per 100,000 in temperate climates to 10 to 100 per 100,000 in tropical climates, but it may occur anywhere and generally outbreaks may occur in slums of the developing world. An estimated 1.03 million cases of human leptospirosis occur worldwide, resulting in 2.9 million disability adjusted life years lost ${ }^{[8]}$. Leptospirosis is also known as Dairy worker fever, Autmnal fever, Cane cutter's disease, Canicola fever, Harvesting fever, Infectious jaundice, Lepro, Mud fever, Rice field worker's disease, Field fever, Eye cather's yellows disease, Seven day fever, Swamp fever, Walter fever, Nanukayami fever, Icterohemorrhagic fever, Swineherd's disease, Hemorrhagic jaundice, Stuttgart disease, Weil's disease, Flabby bag (sudden loss of all milk with flaccid 
udder), Milk drop syndrome, Fort Bragg fever in U.S., Andaman haemorrhagic fever

\section{Historical aspect}

Leptospirosis first described by physician Adolf Weil in 1886 in Germany when he described an "acute infectious disease with enlargement of spleen, jaundice and nephritis" [49]. The etiology of leptospirosis was demonstrated independently in 1915 in Japan. Inada and Ido detected both spirochetes and specific antibodies in the blood of Japanese miners with infectious jaundice thus Inada and Ito first identified Leptospira as the causative organism in $1908^{[18,19]}$ later on Uhlenhuth and Fromme ${ }^{[52]}$ detected spirochetes in the blood of guinea pigs inoculated with the blood of infected soldiers. During World War I, outbreaks confirmed in French, German and British troops as favorable conditions conferred by trench warfare including standing water and rat infestation. Leptospirosis outbreaks during World War II were linked to troops bathing in rivers and streams. Leptospira icterohaemorrhagiae was identified as the causative agent in pre- World War II outbreak in Japan ${ }^{[7]}$.

\section{Etiology}

Leptospira (Greek 'leptos'=fine and Latin 'spira'=coil) are ubiquitous spirochetes. Leptospirosis is caused by Leptospira interrogans (Group 1-Spirochaets). On the basis of pathogenecity genus Leptospira is divided into following two species: (1) L. interrogans consisting of pathogenic strains; (2) L. biflexa consisting of non-pathogenic saprophyte strains. But, the currently used genetically based classification indicates that there are at least 19 species (13 pathogenic and six saprophytic, identified through DNA hybridization analysis ${ }^{[3,5]}$. Among them seven of these species ( $L$. interrogans, $L$. borgpetersenii, L. santarosai, L. noguchii, $L$. weilli, L. kirschneri and L. alexanderi) are the main agents of leptospirosis ${ }^{[1]}$. These species again divided into different serovars (based on difference in agglutination reaction because of the surface lipopolysaccharide) of leptospira. There are approximately more than 225 serovars for $L$. interrogans and more than 60 serovars for L. biflexa ${ }^{[31]}$. The leptospira serovars predominantly present in India are $L$. andamana, L. pomana, L. grippotyphosa, L. hebdomadis, L. semoranga, L. javanica, L. autumnalis, $L$. canicola. Leptospira are thin, flexible, gram negative, motile (with cork-screw like rotating axial filament), helicocidal (spiral) rods $(0.1 \times 6-20 \mu)$ with one or both hooked end(s) give it distinctive question-mark shape. Leptospira is gram negative but it have surface structures that share features of both gram positive and gram negative bacteria. The double-membrane and the presence of LPS are characteristic of Gram-negative bacteria but have lower endotoxic activity $[45,46]$, while the close association of the cytoplasmic membrane with murein cell wall is reminiscent of Gram-positive envelope architecture ${ }^{[10,17,54]}$.

\section{Epidemiology of disease \\ Host range}

1. Reservoir host: Leptospirosis has a very wide range of natural rodent and non-rodent reservoir hosts which include foxes, rabbits, rat, mice, moles etc. Among them the brown rat (Rattus norvegicus) and house mouse (Mus Musculus) is the most important source of human infections as they usually remain carrier throughout their life (permanent carrier). Rodents are therefore considered as the major reservoir of infection. Leptospires have been recovered from amphibians and poikilothermic animals such as frogs and toads ${ }^{[2,12,16] .}$

2. Carrier hosts: Domestic animals carry the microorganisms and therefore act as carrier host for several months (temporary carrier) which includes cattle, sheep, goat, buffalo, horse and dogs.

3. Accidental/ Incidental host: Human act as accidental host of disease.

\section{Mode of transmission}

\section{Leptospirosis is transmitted by the following way}

1. Direct contact with an infected animal. Individuals with occupational risk for direct contact with potentially infected animals include: veterinarians, abattoir workers, farm workers (particularly in dairy milking situations), hunters, trappers, animal shelter workers, scientists and technologists handling animals in laboratories or during fieldwork, where there is presence of water lodging conditions ${ }^{[20]}$. No human to human transmission is reported ${ }^{[55]}$.

2. Indirect contact via soil, water and food contaminated with urine from an infected animal. It is much more common and can be associated with occupational, recreational or avocational activities. The disease has also been associated with swimming, wading and rafting in contaminated lakes and rivers.

3. Transplacental transmission may occur if infection occurs during pregnancy.

4. By infected semen during sexual intercourse.

5. Droplet infection - breathing air polluted with droplets of urine, eg. During milking of cattle and buffalo.

\section{Factors favours emergence of Leptospirosis}

The conditions that are favorable for maintenance and the transmission of the leptospirosis are as follows -

1. Reservoir and carrier host - Together the rodents and the cattle excrete large number of organisms in their urine and thus are responsible for the contamination of soil as well large and small water bodies.

2. Drainage congestion and water logging - Heavy concentrated rainfall leaves a lot of surplus water. Developmental activities like canal network, roads and railway lines obstruct natural drainage of rain water causing its accumulation for longer periods. The water logged areas force the rodent population to abandon their burrows and contaminate the stagnant water by their urine. The farmers and agricultural labourers working in the water logged contaminated fields catch the infection.

3. Soil salinization - In fact, salinity and water logging are inter-linked problems. The salinity of the soil provides favourable environment for survival of leptospires for months together.

4. Soil temperature - The soil of endemic areas in general has lower base saturation and the mean annual soil temperature at the depth of $50 \mathrm{~cm}$ is $22^{\circ} \mathrm{C}$ or more and the difference between mean summer (June-August) and mean winter (December-February) temperature is less than $50{ }^{\circ} \mathrm{C}$. This favours the survival of leptospires for long durations.

5. Urbanization - Incidence of leptospirosis infection among urban children appears to be increasing ${ }^{[28]}$. 
6. Climate change - The interaction of urbanization and climate change has been identified as a significant risk for both increased incidence and increasing frequency of outbreaks of leptospirosis ${ }^{[29]}$. Environment and climatic factors also influence the survival of organism in environment and thus its subsequent transmission. These factors include rainfall, humidity, ambient temperature, water retaining capacity of the soil, $\mathrm{pH}$ and salinity of the soil and surface waters and forest cover ${ }^{[42,43]}$.

7. Gender - Incidence of leptospirosis is much higher in males than females ${ }^{[12,15,23]}$. However, gender differences in leptospirosis incidence are due entirely to exposurerelated bias, as reports of leptospirosis outbreaks related to athletic events where males and females have similar levels of exposure have found no significant effects of gender on development of illness ${ }^{[32,44]}$.

8. Age - Leptospira infections occur more frequently in persons 20-30 years of age group. Leptospirosis rarely occurs in young children and infants, possibly, because of minimal exposure.

9. Seasonal variation - Leptospirosis is usually a seasonal disease that starts at the onset of the rainy season and declines as the rains recede. Sporadic cases may occur throughout the year. More than $97 \%$ of the 2,934 reported leptospirosis cases occurred during the harvest season between August and October, and most commonly affected farmers $\left.{ }^{[9]}(83 \%)\right)$. Tropical climate and high temperatures from March to May, with rainy and humid season between mid-June and November and the annual rainfall is around $3188 \mathrm{~mm}$ favours the transmission of leptospira ${ }^{[34]}$.

10. High risk group - Agricultural workers such as rice field planters, sugar cane and pineapple field harvestors, livestock handlers, labourers engaged in canal cleaning operations are subjected to exposure with leptospires which have reservoir in rodents, cattle, swine, sheep, goats etc. Some occupational groups are - Fishermen, sewer workers and all those persons who are liable to work in rodent infested environment. Lorry drivers and masons - As lorry drivers may use contaminated water to wash their vehicles and masons may come in contact with the organisms while preparing the cement and sand mixture for construction work with contaminated water.

11. Rodent density - The overall prevalence of Leptospira spp. in our rodent sample was $26.7 \%$, a finding in accordance with former studies [6, 50]. No correlation was shown between sex and prevalence but age had a major impact on prevalence, adult animals being much more frequently infected (33.6\%) than juveniles $(17 \%)$, as already described in other locations $[45,46]$. Mice were more frequently infected than rats.

12. Population size of the farm and other domestic animals

13. Sanitation of animal habitats

14. Availability of veterinary services for prompt detection and treatment of animal leptospirosis and control programs

15. Personal hygiene - Personal practices such as bathing in unprotected water bodies; water associated recreational activities, use of protective gear, agricultural and other occupational practices, animal rearing practices, level of hygiene in milking and slaughtering places, etc.

\section{Disinfectant property of leptospira}

Leptospirosis cannot survive dry environment, heat, acids and basic disinfectants but can sustain alkali $\mathrm{pH}$ up to $\mathrm{pH} 7.8^{[21]}$. Leptospirosis are very intolerant of acid - a solution of acetic acid (vinegar) or citric acid (lemon juice) will work as a disinfectant, for example to wash hands on a camping trip. Alcohol is also effective but requires a greater concentration. Swimming pools and some water features will use chlorination tablets. For disinfecting, a dilute bleach solution (1:1 solution of water with $10 \%$ bleach) effectively kills leptospires and can be used for these areas. Quaternary ammonium solutions, alcohol, 1 percent sodium hypochlorite, 70 percent ethanol, glutaraldehyde, formaldehyde, detergents and acid are also among the disinfectants that can also be used for equipment, runs/cages, floors etc ${ }^{[35]}$. Leptospira species is sensitive to moist heat $\left(121^{\circ} \mathrm{C}\right.$ for a minimum of $\left.15 \mathrm{~min}\right)$ and is also killed by pasteurization.

Global distribution of leptospirosis: Leptospirosis are reported from all the continent except Antarctica. Recent information on worldwide human leptospirosis differs but shows that approximately 1 million severe cases occur per year, with a mean case-fatality rate of nearly 10 per cent. The majority of cases occur in men. Estimated 100-200 cases are recognized yearly in the United States, with about $50 \%$ of cases in Hawaii, Indonesia as a nation with high leptospirosis cases, third rank of death rate in the world. Indonesia Ministry of Health gave details that there were 641 human cases in 2013 with casefatality was $9.36 \%$. Outbreak of leptospirosis is not well understood. Epidemic may effect from exposure to flood waters contaminated by urine from infected animal, as has been made clear from several countries. Recreational disclosure and domestic animal contact are well-known sources of leptospirosis. Occupational exposure may be accounts for leptospirosis ${ }^{[41]}$.

Distribution of leptospira in India: According to a NICD report (1997), prevalence rate of leptospirosis is high in Andaman, Bengal, Gujarat, Karnataka, Andhra Pradesh, Tamil Nadu and Kerala. The incidence rate of leptospirosis in the Andaman Islands was estimated to be between 50-65 cases/100,000 per year, which is believed to be the highest in India ${ }^{[43]}$. Prevalence studies being carried out by Indian Veterinary Research Institute during the last 35 years have shown an overall prevalence of $10.1 \%$ during 1975-90, with highest in sheep $(20.6 \%)$. The common serovars identified in animals during the period were Leptospira Pomona, Patoc, Australis, Grippotyposa, Hardjo and Autumnalis. During 1991-2000 the overall sero-positivity marginally increased to $13.4 \%$ which was due to an increase in cases of leptospirosis in cattle $(15.8 \%)$ and dogs $(19.1 \%)$ and the common serovars were RGA, Patoc, Australis, Autumnalis, Grippotyposa, Pyrogens, Ballum, Hardjo, Pomona and Canicola. During the next 5 years (2000-2005) the disease status has remained at an approximated 12 percent. Based on the prevalence studies and distribution of leptospira in animals in different regions, the states have been classified as high prevalence, moderate prevalence and rarely reporting states ${ }^{[56]}$. Leptospirosis can occur in both urban and rural areas. In urban areas of developing countries, a contaminated environment due to various factors such as overcrowding, inadequate drainage and sanitation facilities for man and animals, presence of stray animals, domestic rats, bandicoots, unhygienic slaughter houses and people walking bare foot contribute to the spread of the illness ${ }^{[47]}$. Persons of all ages and races are susceptible. In India, urban leptospirosis has been reported from Chennai 
and Mumbai while rural leptospirosis has been reported from Gujarat, Kerala and Andamans. Non-reporting of leptospirosis from other states of India does not mean that it is absent in those parts ${ }^{[47]}$. Indian scenario leptospirosis is reported to be of endemic importance from many States of India.

Table1 - Distribution of Leptospira serovar in animal in different regions

\begin{tabular}{|c|c|c|}
\hline State & Animal species & Serovar \\
\hline \multicolumn{3}{|c|}{ High prevalence } \\
\hline Tamil Nadu, Kerala, Andaman & cattle, buffalo, sheep, goats, pig & $\begin{array}{l}\text { pyrogenes, pomona, australis, utumnalis, hebdomadis, hardjo, } \\
\text { icterohaemorrhagiae }\end{array}$ \\
\hline \multicolumn{3}{|c|}{ Moderate Prevalence } \\
\hline Maharastra, U.P., M.P., Gujarat, Karnataka & $\begin{array}{l}\text { cattle, buffalo, goats, sheep, pigs, } \\
\text { dogs, horse }\end{array}$ & $\begin{array}{c}\text { pomona, hardjo, canicola, javanica, icterohaemorrhagiae, } \\
\text { pyrogenes }\end{array}$ \\
\hline \multicolumn{3}{|c|}{ Rarely Reported } \\
\hline $\begin{array}{l}\text { Punjab, J\&K, Rajasthan, North Eastern } \\
\text { Hills, Himachal Pradesh }\end{array}$ & cattle, sheep & icterohaemorrhagiae, pyrogenes, canicola \\
\hline
\end{tabular}

Andaman and Nicobar Islands: Andaman and Nicobar Islands are endemic for leptospirosis. Outbreaks of Andaman Hemorrhagic fever were reported since 1988, 524 cases of AHF (leptospirosis) were reported from 1988-97 [42, 43, 47, 48]. This was proved to be leptospirosis in 1994.

Gujarat: The disease is endemic in south Gujarat since 1994. The endemic districts are Valsad, Navsari and Surat ${ }^{[38,47]}$.

Maharashtra: Leptospirosis has been reported repeatedly since 1998. 2355 cases and 167 deaths were reported in 2005, mainly due to large outbreak during the post monsoon floods. The number of districts in Maharashtra reporting leptospirosis has increased from two in 1998 to ten districts in $2005^{[22,47] .}$

Kerala: Leptospirosis is endemic in various parts of Kerala. Kolenchery is in the midlands of Kerala. In this area leptospirosis was rarely diagnosed before $1987^{[27,47]}$.

Tamilnadu: Leptospirosis has been reported from Chennai since 1980's. The leptospirosis laboratory at Institute of Microbiology, Madras Medical College was established in $1994^{[39,40,47]}$

Puducherry: In a study of 33 icteric patients from Puducherry, 22 had altered sensorium and 20 had multi-organ failure and thrombocytopenia and 13 patients died $(39.3 \%)^{[10,}$ 47]

Karnataka: Leptospirosis outbreaks have been reported from 15 districts of Karnataka. The highest incidence of cases have occurred in Bangalore city, Udupi, dakshina kannada, Uttara kannada, Shimoga, Bidar and Gulbarga district. During the year 2004, 152 cases and 11 deaths were reported and during 2005, 224 cases and 19 deaths were reported.

Odisha: After the cyclone during the October-November
1999, 142 patients with febrile illness and hemorrhagic manifestations were evaluated. $28(19.2 \%)$ had evidence of leptospirosis which was confirmed by Microscopic Agglutination Test ${ }^{[47]}$.

Seropositivity rate of leptospira in India (2000-2001) Overall seroprevalence in India was 0 to $46.8 \%$

Table2 Seropositivity rate of leptospira in different regions of India (2000-2001)

\begin{tabular}{|c|c|}
\hline South India & $25.6 \%$ \\
\hline North India & $8.3 \%$ \\
\hline West India & $3.5 \%$ \\
\hline East India & $3.1 \%$ \\
\hline Central India & $3.3 \%$ \\
\hline
\end{tabular}

Other States Data from Andhra Pradesh, Uttar Pradesh, West Bengal and Delhi were analysed. Evaluation of acute febrile patients in Uttar Pradesh revealed that $7 \%$ had leptospirosis (25/346). 17 of the 25 patients had jaundice. In a study of 55 cases of leptospirosis in Hyderabad, $52 \%$ had renal failure and jaundice occurred in $42 \%$. Out of 42 persons with jaundice who were evaluated in Calcutta, $10(23.8 \%)$ were found positive for leptospirosis. 75 patients from Delhi with symptoms of leptospirosis were evaluated, 32 were found positive for leptospirosis and 5 died. 180 febrile patients from urban slums of Delhi were evaluated and 27 (15\%) were positive for leptospirosis ${ }^{[47]}$.

Diagnosis: World Health Organization (WHO) has introduced "Faine's criteria" for diagnosis of leptospirosis, based on clinical history (Part A) and epidemiological history (Part B) supported by laboratory parameters ${ }^{[14]}$ (Part C). Faine's criteria has since been amended to increase the sensitivity of diagnosis ${ }^{[25]}$. Modified Faine's criteria (with amendment) was introduced in 2012.

Table 3 - Faine's criteria for diagnosis of leptospirosis, based on clinical history (Part A) and epidemiological history (Part B) supported by laboratory parameters (Part C).

\begin{tabular}{|c|c|c|}
\hline Part A - Clinical data & Part B - Epidemiological factor & Part C - Bacteriological and laboratory finding \\
\hline Headache (2) & Rainfall & Isolation of leptospira in culture - diagnosis certain PCR \\
\hline Fever (2) & $\begin{array}{c}\text { Contact with contaminated } \\
\text { environment }\end{array}$ & $\begin{array}{c}\text { ELISA IgM positive or SAT positive or MAT- Single } \\
\text { positive in high titer }\end{array}$ \\
\hline Temperature $<39^{0} \mathrm{C}(2)$ & Animal contact & MAT- rising titre \\
\hline Conjunctival suffusion (4) & & Other rapid tests \\
\hline Meningism (4) & & \\
\hline Myalgia (4) & & \\
\hline $\begin{array}{c}\text { Conjunctival suffusion }+ \text { meningism }+ \text { myalgia } \\
(10)\end{array}$ & & \\
\hline Jaundice (1) & & \\
\hline
\end{tabular}




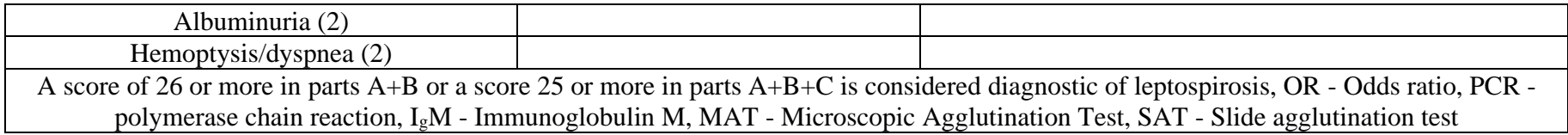

\section{Laboratory diagnosis \\ Specimen collection}

Blood samples were collected in non-additive or gel separator tubes for chemistry and serology and EDTA tube for blood count. For blood culture, blood is inoculated directly into blood culture bottles including culture medium for leptospires.

\section{Microscopic demonstration}

$>$ Dark field microscopy - Approximately $10^{7}$ leptospires/L is required to visualize leptospira. Through examination of blood and urine has both low sensitivity and specificity, it is issue to misunderstanding of fibrin or protein threads. Leptospires are not stained by conventional gram staining.

$>$ Immunofluorescence staining

$>$ Immunoperoxidase

$>$ Silver staining

$>$ Warthin-Starry staining

$>$ Immunohistochemistry

$>$ in situ hybridization

Samples for culture should be collected earlier to the administration of antibiotics. Blood, cerebrospinal fluid and dialysate should be cultured in the first 7 days of the illness (as leptospires disappear from blood after 8 days) and midstream urine from the second week of the illness (leptospires present in urine in the second week of disease and intermittently thereafter upto 6 weeks) but survival of leptospires in human urine is restricted so urine should be processed instantly. To visualize the organism from urine samples after 20 minute neutralize the urine sample by $1 / 10$ $\mathrm{NaOH}$ or buffered it by using 1 per cent bovine serum albumin and to visualize the morphology add $1.5 \mathrm{ml}$ of $10 \%$ formalin (for killing of live microorganism) in $20 \mathrm{ml}$ of urine.

\section{Isolation of Leptospira}

Leptospira are aerobic and microaerophilic. Optimum temperature for their growth is $28-32{ }^{\circ} \mathrm{C}$ and optimum $\mathrm{pH} 7.2-$ 7.5. Culture should observed weekly by dark field microscopy for up to 13 weeks prior to being discarded ${ }^{[33]}$. Vitamins B1 and B12, and long chain fatty acids, are the only organic compounds are required for their growth. The fatty acids are the sole source of carbon and are utilized by $\beta$-oxidation ${ }^{[11]}$. Addition of 5-fluorouracil and antibiotics such as nulidixic acid or rifampicin makes the medium inhibitory for common laboratory contaminants ${ }^{[11]}$.

Table4 Culture medium used for isolation of Leptospira spp.

\begin{tabular}{|c|c|c|c|}
\hline Nature of the media & Serum enriched & Serum replaced by albumin and twin & Chemically defined medium \\
\hline \multirow[b]{3}{*}{ Liquid } & Korthof's & \multirow{3}{*}{$\begin{array}{l}\text { Ellinghausen- McCullough-Johnson-Harris (EMJH) medium - contains } \\
\text { oleic acid, bovine serum albumin and polysorbate } \\
\text { EMJH basal medium, EMJH enrichment medium (10\% enrichment), } \\
\text { EMJH selective medium (5 fluorourocil is added } 200-400 \mathrm{mg} / \mathrm{ml}), \\
\text { PLM-5, Leptospira-5x }\end{array}$} & \multirow[b]{3}{*}{ Shenberg's, Vogel and Hunter } \\
\hline & Stuart's & & \\
\hline & Vervoort's & & \\
\hline \multirow{2}{*}{ Semisolid } & Fletcher's & & \\
\hline & Noguchi’s & & \\
\hline \multirow{2}{*}{ Solid } & Cox's & & \\
\hline & Korthof's & & \\
\hline
\end{tabular}

Growth is detected usually after 6-14 days of incubation. The generation time of leptospires in laboratory media is 12-16 hours and 4-8 hours in inoculated animals. Growth is readily initiated in these media and usually is easily visualized as one or more rings of dense growth several $\mathrm{mm}$ to $\mathrm{cm}$ below the surface of the medium, although a lack of rings of growth does not necessarily mean an absence of leptospires.

\section{Serological diagnosis}

1. The MAT (Micro Agglutination test) - It is considered as the gold standard test in diagnosing leptospirosis according to CDC. MAT test was first explained in 1918 by Martin and Pettit. Live antigens representing diverse serogroups are reacted with serum samples and the agglutination is examined by dark field microscopy. This test is very much specific for particular serovar and sensitivity is also very high.

- Suspected for leptospirosis - If leptospira agglutination titre $>200$ and $<800$

- Confirmed for leptospirosis - If leptospira agglutination titre $>800$

2. Macroscopic agglutination test - Killed antigens representing diverse serogroups are reacted with serum samples and the agglutination is examined by darkfield microscopy. Test is less specific and less sensitive but it is a herd screening test for leptospira.

3. Complement fixation test - Test is very much tedious and complex. Specialized laboratory is needed for this test.

4. ELISA - Antigens of only pathogenic leptospires can react with the monoclonal F9-4 antibodies, can also be used $^{[51]}$. It can detect $\mathrm{I}_{\mathrm{g}} \mathrm{G}$ (chronic infection) and $\mathrm{I}_{\mathrm{g}} \mathrm{M}$ (acute infection) antileptospira antibodies.

5. Latex agglutination test - In this test latex beads are used for adherence of leptospira antigen.

6. Pathogenicity test - Morphologically it is very difficult to differentiate pathogenic and saprophytic leptospira thus conversion to spherical forms in $1 \mathrm{M} \mathrm{NaCl}$, growth in presence of 8 -azaguanine $(225 \mathrm{mg} / \mathrm{l})$ and growth at $13^{\circ} \mathrm{C}$ are conducted. Saprophytes are able to grow at $13^{\circ} \mathrm{C}$ and in presence of 8-azaguanine and also are converted to spherical forms in presence of $1 \mathrm{M} \mathrm{NaCl}$ which the pathogenic bacteria fails to do though $L$. interrogans Icterohaemorrhagiae can grow at $10^{\circ} \mathrm{C}$.

7. Sensitized erythrocyte lysis

8. Patoc slide agglutination test

9. Indirect hemagglutination 
10. Counterimmunoelectrophoresis

11. Microcapsule agglutination

12. Dot-ELISA

13. $\mathrm{I}_{\mathrm{g}} \mathrm{M}$ dipstick

\section{Molecular diagnosis}

1. Polymerase chain reaction (PCR) - Detects DNA in blood in the first 5-10 days after the start of the disease and up to the 15th day by targeting either housekeeping genes, such as $r r s, g y r B$, or $\sec Y$ or pathogen-specific genes such as lipL32, lig or $l f b l^{[1]}$.

2. Loop mediated isothermal amplification method (LAMP)

3. NASBA (Nucleic acid sequence based amplification test)

\section{Differencial diagnosis}

Leptospirosis should be differentiated from Brucellosis, Dengue, Enterovirus infections, Hantavirus pulmonary syndrome, Hepatitis A, Kawasaki disease, Malaria, Measles, Meningitis, Q fever.

\section{Pathogenesis}

The bacteria enter the body through small abrasions, mucosa, conjunctiva and genital tracts. It involves some chemotactic interactions and then transmembrane passage. The bacteria settle down in the convoluted tubules of the kidney and thus keep on shedding the pathogen in urine. The period of shedding varies from a few weeks to many months. After the bacteria reach a higher concentration in blood and tissue, there is tissue damage due to endotoxins secreted by the pathogen. Hemolysin is also secreted by the bacteria and leads to damage of blood cells. Endothelium gets damaged which leads to ischemia and other complications. The exact molecular basis of virulence is yet unknown however the humoral response has been observed to be active in first week of infection leading to phagocytosis by macrophages and neutrophils ${ }^{[31]}$.

\section{Signs and Symptoms}

Symptoms can take 2 to 26 days (average 10 days) to develop and may include:

In humans: The disease is characterized by variety of symptoms, including high fever, vomiting, jaundice (yellow skin and eyes), red eyes, headache, chills, muscle aches, abdominal pain, diarrhoea, rash etc. Some infected persons may have no symptoms at all. Illness usually begins abruptly with fever and other symptoms. The symptoms appear after an incubation period of 7-12 days. Leptospirosis may occur in two phases-

- The first phase (acute or septic phase) ends after 3-7 days of illness with the appearance of antibodies against leptospira and the disappearance of all the bacteria from the bloodstream.

- The patient is asymptomatic for 3-4 days until the second phase begins with another episode of fever. The hallmark of the second phase is meningitis (inflammation of the membranes covering the brain) the illness lasts from a few days to 3 weeks or longer. Severe leptospirosis is known as Weil's disease, which is characterized by liver damage, kidney failure and bleeding. The disease affects brain causing meningitis, encephalitis and affects lung as the most serious and life-threatening of all leptospirosis complications.

\section{Treatment}

Antibiotics like amoxicillin, doxycycline, ceftriaxone etc. are used. Fluid therapy can be advised as per the requirement. Persons with symptoms suggestive of leptospirosis should contact a health care provider as soon as possible.

\section{Prevention and control}

The global leptospirosis environmental action network (GLEAN) is a one health approach to reduce the impact that leptospirosis outbreaks have on communities through providing cost-effective, implementable and sustainable solution. Early warning system and improved prevention and control strategies increase the knowledge of the relationship between environmental, biological, ecological, economic, demographic factors. Intervention strategies can target many points in the transmission cycle of leptospirosis:

1. Leptospirosis in domestic animals can be controlled through vaccination with inactivated whole cells or an outer membrane preparation ${ }^{[37]}$.

2. Rodent control preferably through the use of slow acting rodenticides and improved environmental hygiene to eliminate possibility of water, soil and food contamination are some of the measures for diminishing the risk of leptospirosis transmission.

3. Occupational hygiene that includes the use of water proof shoes and gloves is fundamental for preventing human leptospirosis ${ }^{[24]}$.

4. The mass awareness or public education is of utmost importance.

5. Do not allow animals to urinate in or near ponds or pools.

6. Keep animals away from gardens, playgrounds, sandboxes, and other places children may play.

7. Chlorination is seldom useful, as virulent leptospires withstand up to $4 \mathrm{ppm}$ in potable water. Filtered water is not safe thus using boiled or ultraviolet irradiated water is advisable.

8. Water tanks must be sealed if possible. Bathroom and kitchen waste pipes must be blocked at night.

9. Try avoiding walking in flood water. If you have to, wear gum boots.

10. Heavy drinking and smoking predispose damage to the liver and the kidneys which in turn become vulnerable to leptospiral infection.

11. Proper collection, transport, treatment and secured disposal of garbage.

\section{Conclusion}

A climatic condition influences the transmission of disease by altering human exposure, animal host population dynamics and environmental conditions that allow Leptospira spp. to persist in the environment. Incidence of leptospirosis especially high amongst farmers may be associated with rice harvest and modulated by prior bacterial accumulation within the soil under moist conditions. Reservoirs control measures, environmental control programs and animal vaccination, in combination with a strong surveillance system may significantly reduce the disease. The extensive and good understanding of the eco-epidemiological and cultural characteristics of a community that faces the problem of leptospirosis is an essential prerequisite for evolving an effective and acceptable control measure.

\section{References}

1. Ahmed N, Devi SM, De los Á Valverde M, Vijayachari 
$\mathrm{P}$, Machang'u RS et al. Multilocus sequence typing method for identification and genotypic classification of pathogenic Leptospira species. Annals of clinical microbiology and antimicrobials 2006;5(1):28.

2. Babudieri B, Carlos ER, Carlos Jr ET. Pathogenic leptospira isolated from toad kidneys. Tropical and geographical medicine 1973;25(3):297-9.

3. Bharti AR, Nally JE, Ricaldi JN, Matthias MA, Diaz MM, Lovett MA et al. Leptospirosis: A zoonotic disease of global importance. The Lancet infectious diseases 2003;3(12):757-71.

4. Blasdell KR, Morand S, Perera D, Firth C. Association of rodent-borne Leptospira spp. with urban environments in Malaysian Borneo. PLoS neglected tropical diseases 2019;13(2):e0007141.

5. Brenner DJ, Kaufmann AF, Sulzer KR, Steigerwalt AG, Rogers FC, Weyant RS. Further determination of DNA relatedness between serogroups and serovars in the family Leptospiraceae with a proposal for Leptospira alexanderi sp. nov. and four new Leptospira genomospecies. International Journal of Systematic and Evolutionary Microbiology 1999;49(2):839-58.

6. Bunnell JE, Hice CL, Watts DM, Montrueil VI, Tesh RB, Vinetz JM. Detection of pathogenic Leptospira spp. infections among mammals captured in the Peruvian Amazon basin region. The American journal of tropical medicine and hygiene 2000;63(5):255-8.

7. Christopher GW, Agan BK, Cieslak TJ, Olson PE. History of US military contributions to the study of bacterial zoonoses. Military medicine 2005;170:39-48.

8. Costa F, Hagan JE, Calcagno J, Kane M, Torgerson P, Martinez-Silveira MS. Global morbidity and mortality of leptospirosis: a systematic review. Plos negl trop dis 2015;9(9):e0003898.

9. Cucchi K, Liu R, Collender PA, Cheng Q, Li C, Hoover $\mathrm{CM}$ et al. Hydroclimatic drivers of highly seasonal leptospirosis incidence suggest prominent soil reservoir of pathogenic Leptospira spp. in rural western China. PLoS neglected tropical diseases 2019;13(12):e0007968.

10. Dutta TK, Christopher M. Leptospirosis - An Overview. J Assoc. Phys. India 2005;52:545- 551.

11. Evangelista KV, Coburn J. Leptospira as an emerging pathogen: a review of its biology, pathogenesis and host immune responses. Future microbiology 2010;5(9):141325.

12. Everard CO, Carrington D, Korver H, Everard JD. Leptospires in the marine toad (Bufo marinus) on Barbados. Journal of Wildlife Diseases 1988;24(2):334-8.

13. Everard CO, Bennett S, Edwards CN, Nicholson GD, Hassell TA, Carrington DG. An investigation of some risk factors for severe leptospirosis on Barbados. The Journal of tropical medicine and hygiene 1992;95(1):1322.

14. Faine S. Guidelines for the control of leptospirosis. Geneva: World Health Organization 1982,67.

15. Guerra-Silveira F, Abad-Franch F. Sex bias in infectious disease epidemiology: patterns and processes. PloS one 2013;8(4):e62390.

16. Gravekamp C, Korver H, Montgomery J, Everard CO, Carrington D, Ellis WA et al. Leptospires isolated from toads and frogs on the Island of Barbados. Zentralblatt für Bakteriologie 1991;275(3):403-11.

17. Haake DA. Spirochaetal lipoproteins and pathogenesis.
Microbiology 2000;146(7):1491-504.

18. Inada R. Areport on the discovery of the causative organism (a new spesies of spirochete) of Weil's disease. Tokyo Ijishinshi (Tokyo Med J) 1915;1908:351-60.

19. Inada R, Ido Y, Hoki R, Kaneko R, Ito H. The etiology, mode of infection, and specific therapy of Weil's disease (Spirochaetosis icterohaemorrhagica). The Journal of experimental medicine 1916;23(3):377.

20. James WD, Berger TG, Elston DM. Epidermal nevi, neoplasms, and cysts. Andrews' diseases of the skin. Clinical dermatology. Tenth edition. Saunders Elsevier 2006,633-83.

21. Johnson RC, Faine Leptospira S. In: Krieg, N.R. and Holt, J.G. (eds.) Bergey's manual of systematic bacteriology. Williams \& Wilkins, Baltimore 1984;1:6267.

22. Karande S, Kulkarni H, Kulkarni M, De A, Varaiya A. Leptospirosis in children in Mumbai slums. The Indian Journal of Pediatrics 2001;69(10):855-8.

23. Katz AR, Buchholz AE, Hinson K, Park SY, Effler PV. Leptospirosis in Hawaii, USA, 1999-2008. Emerging Infectious Diseases 2011;17(2):221.

24. Koutis CH. Special epidemiology. Editions, Technological Educational Institute of Athens. Athens, Greece 2007;7:87-90.

25. Kumar SS. In: Indian Guidelines for the Diagnosis and Management of Human Leptospirosis. Muruganathan A, editor. India: Medicine Update 2013,23-29.

26. Kumbhare MR, Surana AR, Arote RA, Borse GD. Current Status of Leptospirosis: A Zoonotic Tropical Disease. Int J Microbiol Curr Res 2019;1(1):14-9.

27. Kuriakose M, Eapen CK, Paul R. Leptospirosis in Kolenchery, Kerala, India: Epidemiology, prevalent local serogroups and servoars and a new serovar. European journal of epidemiology 1997;13(6):691-7.

28. Langston CE, Heuter KJ. Leptospirosis: A re-emerging zoonotic disease. Veterinary Clinics: Small Animal Practice 2003;33(4):791-807.

29. Lau CL, Smythe LD, Craig SB, Weinstein P. Climate change, flooding, urbanisation and leptospirosis: fuelling the fire?. Transactions of the Royal Society of Tropical Medicine and Hygiene 2010;104(10):631-8.

30. Levett PN. Leptospira. Manual of clinical Microbiology 2015,1028-36.

31. Mohammed H, Nozha C, Hakim K, Abdelaziz F, Rekia B. Leptospira: morphology, classification and pathogenesis. J Bacteriol Parasitol 2011,2(06).

32. Morgan J, Bornstein SL, Karpati AM, Bruce M, Bolin CA, Austin CC et al. Outbreak of leptospirosis among triathlon participants and community residents in Springfield, Illinois, 1998. Clinical Infectious Diseases 2002;34(12):1593-9.

33. Musso D, La Scola B. Laboratory diagnosis of leptospirosis: A challenge. J Microbiol Immunol Infect 2013;46(4):245-252.

34. National Informatics Centre. Ratnagiri City and District Information. Available from: http://www.ratnagiri.nic.in/gazetter/gom/home.html/2006.

35. National Association of State Public Health Veterinarians: Veterinary Infection Control Committee. Compendium of Veterinary Standard Precautions for Zoonotic Disease Prevention in Veterinary Personnel. J Am Vet Med Assoc 2010;237(12):1403-1422.

36. NICD. Communicable Diseases. CD Alert Newsletter 
1997.

37. Palaniappan RU, Chang YF, Jusuf SS, Artiushin S, Timoney JF, McDonough SP et al. Cloning and molecular characterization of an immunogenic Lig A protein of Leptospira interrogans. Infection and immunity 2002;70(11):5924-30.

38. Patel BK, Gandhi SJ, Desai DC. Clinico-epidemiological aspect of leptospirosis in South Gujarat. Indian journal of medical microbiology 2006;24(4):322.

39. Pradeep KS, Sumathi G, Rao GV, Kumar SS. Leptospirosis laboratory, Chennai Medical College: A three year experience in serodiagnosis (1995-1997). Indian Journal of Medical Microbiology 1999;17(1):50.

40. Ratnam S, Sundararaj T, Thyagarajan SP, Rao RS, Madanagopalan N. Serological evidence of leptospirosis in jaundice and pyrexia of unknown origin. Indian journal of medical research 1983;77:427-30.

41. Scoot GM, Coleman TJ. (209) Leptospirosis. In: Farrar J, Hotez P, Junghanss T, Kang G, Lalloo D, White NJ (eds). Manson's tropical diseases. 23rd edition 2014.

42. Kumbhare MR, Surana AR, Arote RA, Borse GD. Current Status of Leptospirosis: A Zoonotic Tropical Disease. Int J Microbiol Curr Res 2019;1(1):14-9.

43. Sehgal SC. Epidemiological patterns of leptospirosis. Indian journal of medical microbiology 2006;24(4):310.

44. Sehgal SC. Emergence of leptospirosis as a public health problem. In Leptospirosis. Proceedings of the third Round Table Conference, New Delhi Ranbaxy Science Foundation: Gurgaon 1998;23:7-16.

45. Sejvar J, Bancroft E, Winthrop K, Bettinger J, Bajani M, Bragg S et al. Leptospirosis in "eco-challenge" athletes, Malaysian Borneo, 2000. Emerging infectious diseases 2003;9(6):702.

46. Shimizu MM. Environmental and biological determinants for the prevalence of leptospirosis among wild small mammal hosts, island of Hawaii. International journal of zoonoses 1984;11(2):173.

47. Shimizu T, Matsusaka E, Takayanagi K, Masuzawa T, Iwamoto $\mathrm{Y}$, Morita $\mathrm{T}$. Biological activities of lipopolysaccharide-like substance (LLS) extracted from Leptospira interrogans serovar canicola strain Moulton. Microbiology and immunology 1987;31(8):727-35.

48. Shivakumar S. Leptospirosis-current scenario in India. Medicine 2008;18:799-809.

49. Singh SS, Vijayachari P, Sinha A, Sugunan AP. Clinicoepidemiological study of hospitalized cases of severe leptospirosis. Indian Journal of Medical Research. 1999; 109:94.

50. Stimson AM. Note on an organism found in yellow-fever tissue. Public Health Reports (1896-1970) 1907;3:541.

51. Suepaul SM, Carrington CV, Campbell M, Borde G, Adesiyun AA. Serovars of Leptospira isolated from dogs and rodents. Epidemiology \& Infection 2010;138(7):1059-70.

52. Terpstra WJ. Human leptospirosis: guidance for diagnosis, surveillance and control. World Health Organization 2003.

53. Uhlenhuth P. Experimintelle Untersuchungen uber die sogenannte Weilsche Krankheit (ansteckende Gelbsucht). Med Klin 1915;44:1202-3.

54. United Nations, Department of Economic and Social Affairs, Population Division. World Urbanization Prospects 2018.

55. Vijayachari P, Sugunan AP, Shriram AN. Leptospirosis: an emerging global public health problem. Journal of biosciences 2008;33(4):557-69.

56. Wasinski B, Dutkiewicz J. Leptospirosis-current risk factors connected with human activity and the environment. Annals of Agricultural and Environmental Medicine 2013, 20(2).

57. WHO. Report of the Brainstorming meeting on Leptospirosis Prevention and Control 2006. 